\title{
ウクライナにおける地域ファクターと歴史観 \\ ——ユーロマイダン革命」以後の社会調查データをもとに— \\ 保 坂 三四郎 \\ Revisiting the Regional Factor in Post-Maidan Ukraine: Quantitative Analysis of the Nationwide Survey Data on Historical Memory
}

\author{
HosaKa, Sanshiro
}

\begin{abstract}
Are there any experts who successfully predicted how the Ukrainian crisis would unfold after the Euromaidan revolution? On the one hand, the "Russian spring" project obviously failed: Vladimir Putin's call for consolidating "Novorussia" did not catch the hearts of people beyond the limited part of Donbass. For example, after the launch of antiterrorist operations in spring 2014, even such a Russified eastern city as Dnipropetrovsk turned blue-and-yellow, full with volunteer citizens supporting the government forces, thereby exhibiting the rise of Ukrainian patriotism. However, that was not the end of the story. During the national parliament elections in October, 2014 in the same Dnipropetrovsk Oblast the Opposition Bloc consisting of former Party-of-Regions members that did not endorse the Euromaidan surpassed the president's party, Petro Poroshenko Bloc. Other eastern regions such as Kharkiv and Zaporizhzhia mirrored Dnipropetrovsk in their electoral behavior. These snapshot observations speak for themselves: the social and political dynamics in Ukraine is much more complicated than is routinely described with the popular "east-west divide" discourse.

Quantitative research on the mass attitudes in Ukraine often opts for versatile "regions" to explain the social and political cleavages. Most of them, however, treat regions as proxy for historical and cultural attributes common to localities, ignoring the heterogeneous distribution of personal historical memories in a given geographical space. This study tests the explanatory power of individual acceptance of national history in shaping the attitudes toward the Euromaidan, utilizing ordered logit model on nationwide survey data collected from December 2014 to January 2015.

The author ran principal component analysis on the responses to the seven major historical events in Ukraine, and identified anti-Ukraine historical component, which denies the Ukrainian Insurgent Army as well as the collapse of the USSR and the country's independence. In the ordered logit estimation with these principal component scores, the effect of the regional factor was mediated by historical memory in all eastern regions in-
\end{abstract}

Keywords: Ukrainian crisis, Historical memory, Mass attitudes, Identity politics 
cluding Donbass, Sloboda, Lower Dniepr and Black Sea. However, explanatory power of the regional variable persists in Podolia and Left bank. This finding suggests the further need for studying interaction terms between historical memory and regions.

Furthermore, two-stage least square estimation with instrumental variable was conducted to verify the effect of historical memory on the attitudes to the Euromaidan, which rejected the above hypothesis at a five-percent significance level. This implies that causal arrows run reciprocally between these two variables.

The analysis also discovered the carriers of ambivalent "hybrid" memory, who miss the Soviet Union but welcome the independence simultaneously. These findings provide valuable insights into the amorphous nature of the eastern regions that embrace multilayered historical memories, and highlight key challenges for post-Maidan national (re)integration.

\section{は じめに}

2013 年 11 月末に EU 連合協定調印延期への抗議活動として始まったウクライナの「ユーロ マイダン革命」（以下「ユーロマイダン」）は，翌年 2 月のヤヌコヴィッチ大統領の首都脱出, 3 月のロシアによるクリミア併合, 東部の騒擾へとつながり, 一時は国家の「分裂」すら危惧 された。しかし，その後のウクライナの政治・社会情勢は当事者の誰もが予想しえなかった方 向に展開している。

第一に, プーチンが期待した「ロシアの春」は訪れなかった。現代型「ノヴォロシア」(Putin 2014b）への共感はドンバスの一部地域を越えて広がることはなかった。例えば,「ロシア化」 されていたはずの東部の都市ドニプロペトロウシクは 2014 年春の対テロ作戦開始以降, 町全 体が青と黄のウクライナ国旗色に染まり，ボランティア市民が政府軍側を支援するなど，愛国 心の高揚が見られたことは多くの観察者を驚かせた（Portnov 2015）。

第二に, ウクライナにとっても春は遠かった。2014年 10 月にドニプロペトロウシク州で実 施された最高会議（議会）選挙では, 旧地域党の残勢力を吸収した野党連合が大統領率いるぺ トロ・ポロシェンコ連合を抜いて首位に躍り出た。同じ東部のハリキゥ州，ザポリッジャ州も 同様の傾向を見せた（Zhurzhenko 2015, 46-47）。

このようなウクライナ社会の内的変化に直面した Riabchuk（2015）は，ソ連崩壊直後に自 ら提唱した「二つのウクライナ」論を修正せざるをえなかった。

$(…$.$) ウクライナの主要かつ唯一重要な亀裂は, 民族的なロシア人とウクライナ人, ロシ$ ア語話者とウクライナ語話者,「東」と「西」の間にあるのではない。主要な亀裂はイデオ ロギーに関するものであり, それは非/反ソ連とポスト/ネオソ連, あるいは「ヨーロッパ」 と「東スラヴ」といら二つの異なるタイプのウクライナのアイデンティティの間にある $(\cdots . . .$.

Riabchuk のいらアイデンティティの問題は, ひとりひとりの国民がウクライナの歩んできた 過去をいかに捉えているかという問題に置き換えることができよう。独立後のウクライナに㧤 いて, 17 世紀にフメリニッキーがモスクワ国と締結したペレヤスラフ協定や第二次大戦期の 対独・対ソ連闘争などの解釈は人々の感情を刺激するセンシティブな問題である (Plokhy 2001; 
Portnov 2010)。歴史論争はさらに地域間のステレオタイプと結びつき，選挙時の有権者動員 など主に国内政治の文脈で利用されてきたが（Osipian \& Osipian 2012; Portnov 2013)，2014 年 のユーロマイダンは歴史問題が大衆扇動に引き続き有効であるだけでなく, 隣国が国境を越光 てウクライナ国民に影響力を行使する強力な兵器にもなることを示した (Putin 2014a) ${ }^{(1)}$ 。

一方, ウクライナの政治態度の計量分析に抢いては地域変数の効果が大きいことが多くの研 究によって指摘されているが (i.e. Birch 2000; Barrington 2002; Barrington \& Herron 2004; Katchanovski 2006; Barrington \& Faranda 2009) (2)，歴史観に着目した研究はいまだ少ない。例 えば，有権者の投票行動に抢ける歴史的要因に注目したBirch（2000）やKatchanovski（2006） は, 所与の「歴史的地域」(「旧ハプスブルグ領」「旧オスマン帝国領」等), あるいは各州の「口 シア・ソ連に支配されなかった期間」を説明変数とするが，個人の歴史認識の効果そのものを 測定したものではない。

しかしながら，地域の歩んだ歴史と居住者の歴史認識との間に高い相関を仮定する議論は, コンテクストの力を過剩評価しているょうに思われる。例えば,「ウクライナ化」された西部 に抢いてもソ連時代に愛着を持つ人,「ロシア化」された東部に抢いても反ソ連感情の強い者 がきっと見つかるだろう。現代人の高い移動性やさまざまなメディアを経由した情報の拡散・ 受容を考旮ば，単一の歴史的地域のなかにも多様な歴史観が観察されて何ら不思議はない。 社会学者の Zaharchenko（2013）によれば，住民の大半がロシア語話者でありながら，ウクラ イナのアィデンティティを保持するハリキウのように多くの地域は東西いずれの典型像にも当 てはまるものではなく, 流動的, 中間的なアィデンティティを含む多様性（ポリフォニー）が 現代ウクライナの特徴であるといら。

本研究は, 2014 年末頃にウクライナの調査機関が実施した社会調査の個票データの 2 次分 析を通して，ウクライナ国民の政治態度の分析に拈いて歴史・文化的要因の代理変数と久なさ れてきた地域变数から歴史観を分離し, その特徵を観察するとともに, 歴史観が地域変数とユー ロマイダンへの態度をつなぐ媒介関係にあるかどうかを定量的に検証することを目的とする。

第 1 節は，原調查の内容とデータクリーニング等の事前準備に触れた後，主成分分析及びク ラスター分析によって歴史観变数を合成する。第 2 節は, この歴史観変数と地域, 民族等との 関連を分析する。第 3 節は, ユーロマイダンへの態度を目的変数とする順序ロジットモデルに 従来の地域変数等に加えて歴史観を投入し，地域変数の効果の変化を確認する。

な挔，調査はユーロマイダンが最高潮を迎えた，ヤヌコヴィッチ大統領の首都脱出（2014 年 2 月）から 10 か月以上が経過した時点で行われた。この間に生じたクリミア併合やドンバ スの紛争が調査対象者の歴史観に影響を与えた可能性がある。すなわち, 歴史観が先行してユー ロマイダンへの態度を決定したのではなく, ユーロマイダンへの態度が調査時の歴史観を形成 または修正したかもしれない。本稿ではこのよらなユーロマイダンへの態度と歴史観の間にあ る双方向の影響を考慮し, 操作変数法を利用することで順序ロジットの推定結果の頑健性も追 加的に検証した。

(1) プーチン大統領は 2014 年 3 月のクリミア併合演説においてソ連プロパガンダと同じレトリックでユー ロマイダンと第二次大戦時にナチスに協力した「残虐な」ウクライナ民族主義に関する歴史的記憶を リンクさせた。

(2) 例外として, 地域効果を「偽りの効果 (“effect” of bogus)」と呼んだ政治地理学者 O’Loughlin（2001） の研究がある。 


\section{1 歴史観変数の合成}

\section{(1) 原調査の概要}

本研究が分析に使用するのは，2014年 12 月 25 日から 2015 年 1 月 15 日にかけてイリコ・ クチェリウ民主主義イニシアティブ財団等が実施した世論調査「何がウクライナ人を統合及び 分離するか」（以下「原調査」という）（DIF 2015a）の個票データである ${ }^{(3)}$ 。原調査は, ユー ロマイダン以後の各地域の住民を分断する要因, 国民の和解へ向けた態度, ドンバスやクリミ アの状況に対する態度，各地域の住民の対外政策志向，社会文化的志向，ハリチナとドンバス の間のステレオタイプ，各地域の歴史観などを推定する目的で実施された。単独区分されたキ エフ市，行政区画の州を $1 \sim 4$ 単位組久合わせた領域から成る計 11 の「歴史的地域」を定義 したらえで各地域から割当法によって 18 歳以上の住民を約 400 人ずつ, 計 4413 人を抽出して いる(4)。ルハンシク州で調査は実施されなかったため, ドネック州のみが「ドンバス」を代表 しているが，同州の標本はウクライナ政府管轄地域と非管轄地域（親露派支配地域）で等分し て抽出された。また, ロシアに併合されたクリミア自治共和国は原調査の対象外となっている。

調査項目は年齢, 性別等のデモグラフィックも含め計 113 の設問から成るが，歴史認識に関 する質問は前半に登場し，10 世紀末のキエフ・ルーシのキリスト教受容に始まり，ウクラィ ナに関係する 20 以上の歴史的出来事への態度を 4 つの選択肢（肯定的，否定的，ぞちらとも いえない，知らない）から選択させている。

\section{（2）分析の準備}

分析データの信頼性を確保するため, 歴史的出来事の全設問に同一の回答をしている者（全 てに「肯定的」 260 人,「どちらともいえない」 113 人，「知らない」33人）を分析対象から除 外した。

主成分分析やクラスター分析は連続变数を必要とするため, 回答の「肯定的」を「1」，「否 定的」を「-1」，「ぞちらともいえない」を「0」に置換したが，「知らない」は分析対象から除 いた。な拉，これらの分析法は欠損值があると計算ができないため，結果的にひとつでも「知 らない」を含む個票をリストワイズ削除せざるをえないが，本件データの「知らない」は完全 にランダムに生じる欠損值（MCAR）ではないため, リストワイズ削除は選択バイアスのリス クを伴う。例えば, 独立後のウクライナ史学では重視されるが一般にあまり知られていない「コ ノトプの戦い」を「知らない」と回答する個票を全て削除すれば残った標本はウクライナ史に 関心がある者に偏ってしまら。本稿はこのよらなバイアスを最小化するため, 分析対象は比較 的よく知られる 7 項目に絞り, これらの項目に対する評価の平均值がリストワイズ削除の前後 で大きく変わらないことを確認した ${ }^{(5)}$ 。以上の作業を経て最終的な標本は 2833 名となった。

(3) 個票データは 2015 年 10 月 13 日にイリコ・クチェリウ民主主義イニシアティブ財団から筆者に対し て提供された。公表された集計結果は Panchenko（2015）などの研究に引用されているが，個票デー タに基づく分析はほとんどないよらである。

(4) 議会選挙の有権者数に応じ, 州に標本を比例割当し, 州都のほか市町村を無作為抽出。調査者は指定 された街路に捻いて, 統計データから算出した性と年齢の割当に従って調査対象者を抽出した。標本 抽出法の詳細は DIF（2015b）参照。

(5) 多重代入法を用いて他の観測値から計算によって「知らない」に当てはまる値を推測して補完するこ とも可能であるが，再現性が確保できなかったため適用は見合わせた。 
また，原調査はジトームィル州，スームィ州等を「ポリーシャ」，チェルカースィ州，ポル タワ州等を「中央部」としてそれぞれ東西に横長の領域に区分するが，ロシア帝国への編入時 期等を考えるとドニェプル川の左岸と右岸の州を同じ「歴史的地域」として扱らのはやや無理 があると考えられるため，本稿ではこれらの州を「右岸」と「左岸」に組み替えた。

最終的な歴史項目と地域区分は表 1 ，基本統計量は表 2 のと扣りである。

\section{(3) 変数の合成}

上記データに対して分散共分散行列を用いた主成分分析を行い，固有べクトルを得た（表 3 上部。第 6 主成分以下は省略)。第 1 主成分（寄与率 43.7\%）は，ソ連崩壊やウクライナ独立， ウクライナ民族主義を象徵するUPA に対し負の值なので，「アンチウクライナ」と命名する。 また，第 2 主成分（15.0\%） はソ連崩壊や独立に正の值をとりつつも，ソ連・ロシア史学がウ クライナ民族と「兄弟的」ロシア民族の統合の象徵として礼賛するペレヤスラフ協定の正の值 が際立って高いことから「独立ウクライナとロシアは兄弟」と命名した。第 3 主成分以下は解 釈が難しいが表のと颃り暫定的に命名した。

また， ウクライナ国民の典型的な歴史観の分類を示すため, 同じデータに対してウォード法 による階層的クラスター分析を行い, 歴史観が似通ったクラスターを形成し, 各クラスターが 解釈可能となる高さで樹形図を切った。こうして形成された計 7 クラスターを平均值に基づき 解釈した結果は表 3 下部のと抢りである。クラスター化によって各個票の持つ情報量の一部が

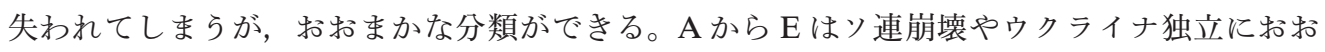
む敉肯定的であるので，大きく「ウクライナ型」と括れる。さらに分類すると A と D はペレ ヤスラフ協定に否定的であることから「ウクライナ型/反ロシア」, B はペレヤスラフ協定に は中間的態度であることから「ウクライナ型/対ロシア中立」, C はペレヤスラフ協定にも肯

表 1 歴史的出来事と歴史的地域

※アルファベット表記は解析に打ける略称

\section{歴史的出来事}

1） 998 年ルーシ・キリスト教受容 “RusChrist”

2) 1648 年ボフダン・フメリニッキーの民族解放戦争 “Khmelnytsky”

3） 1654 年ペラヤスラフ協定後のウクライナとモスクワ国との新たな関係 (いわゆる統合) “Pereyaslav”

4) 1942 年ウクライナ蜂起軍 (UPA) の創設 “UPA”

5） 1945 年ソ連，第三帝国（筆者注：ナチスドイッ）に勝利“WinNazis”

6） 1991 年ソ連崩壊 “USSREnd”

7） 1991 年ウクライナ独立宣言 “Independence”

\section{歴史的地域}

1) ハリチナ（イヴァーノ＝フランキーウシク州，リヴィウ州，テルノーピリ州）

2) ヴォルィーニ（ヴォルィーニ州，リウネ州）

3) 南西部（ザカルパッチャ州, チェルニウッィー州)

4) ポジーリャ（ヴィーンヌィツャ州，フメリヌィーツィクィ州）

5) 右岸（ジトームィル州, キェフ州, チェルカースィ州, キロヴォフラード州)

6) 左岸（スームィ州，チェルニーヒウ州，ポルタワ州）

7）スロボダ（ハリキウ州）

8）ドニエプル下流（ドニプロペトロウシク州，ザポリージャ州）

9）黑海沿岸（ムィコラーイウ州, オデッサ州, ヘルソン州)

10）ドンバス（ドネック州）

11）キエフ市 
表 2 基本統計量

\begin{tabular}{|c|c|c|c|c|c|c|c|}
\hline \multirow[t]{3}{*}{ 性別 } & 男性 & 1292 & $45.6 \%$ & \multirow[t]{5}{*}{ 民族属性 } & ウクライナ人 & 2458 & $86.8 \%$ \\
\hline & 女性 & 1541 & $54.4 \%$ & & ロシア人 & 293 & $10.3 \%$ \\
\hline & 計 & 2833 & $100.0 \%$ & & その他 & 79 & $2.8 \%$ \\
\hline \multirow[t]{7}{*}{ 世代 } & 30 歳未満 & 655 & $23.1 \%$ & & NA & 3 & $0.1 \%$ \\
\hline & 30 代 & 585 & $20.6 \%$ & & 計 & 2833 & $100.0 \%$ \\
\hline & 40 代 & 455 & $16.1 \%$ & \multirow[t]{7}{*}{ 使用言語 } & ウクライナ語のみ & 939 & $33.1 \%$ \\
\hline & 50 代 & 587 & $20.7 \%$ & & ウクライナ語多い & 738 & $26.1 \%$ \\
\hline & 60 歳以上 & 550 & $19.4 \%$ & & ロシア語多い & 704 & $24.8 \%$ \\
\hline & NA & 1 & $0.0 \%$ & & ロシア語のみ & 419 & $14.8 \%$ \\
\hline & 計 & 2833 & $100.0 \%$ & & その他 & 20 & $0.7 \%$ \\
\hline \multirow[t]{12}{*}{ 居住地域 } & ハリチナ & 316 & $11.2 \%$ & & NA & 13 & $0.5 \%$ \\
\hline & ヴォルイーニ & 306 & $10.8 \%$ & & 計 & 2833 & $100.0 \%$ \\
\hline & 南西部 & 217 & $7.7 \%$ & \multirow{5}{*}{$\begin{array}{l}\text { マイダン } \\
\text { への態度 }\end{array}$} & 肯定的 & 1665 & $58.8 \%$ \\
\hline & ポジーリヤ & 230 & $8.1 \%$ & & 否定的 & 933 & $32.9 \%$ \\
\hline & 右岸 & 247 & $8.7 \%$ & & どちらともいえない & 218 & $7.7 \%$ \\
\hline & キエフ市 & 259 & $9.1 \%$ & & NA & 17 & $0.6 \%$ \\
\hline & 左岸 & 215 & $7.6 \%$ & & 計 & 2833 & $100.0 \%$ \\
\hline & 黒海沿岸 & 226 & $8.0 \%$ & & & & \\
\hline & ドニエプル下流 & 305 & $10.8 \%$ & & & & \\
\hline & スロボダ & 261 & $9.2 \%$ & & & & \\
\hline & ドンバス & 251 & $8.9 \%$ & & & & \\
\hline & 計 & 2833 & $100.0 \%$ & & & & \\
\hline
\end{tabular}

定的であることから「ウクライナ型／親ロシア」，EはUPA に否定的であることから「ウクラ イナ型／反民族主義」とする。一方，F はソ連崩壊とウクライナ独立に否定的な傾向があるの で「ソ連型／反独立」，G はソ連崩壞には否定的でありながら独立を肯定するので「ソ連型／ ハイブリッド」と命名する ${ }^{(6)}$ 。な和，「ソ連型／反独立」は主成分分析で得た第 1 主成分「ア ンチウクライナ」の特徵と扮拈む叔重なる。

\section{2 歴史観の分布}

第 1 節で合成した歴史観に関する主成分得点について，世代，居住地域，民族属性及び使用 言語の各群間の得点分布を箱ひげ図で示すとともに，ボンフェローニ法による多重比較を行っ て各要因の群間の差を検定した。また, 世代と居住地域については歴史観クラスターの分布状 況をグラフにして視覚的な把握を試みた。

(6) ソ連崩壊を惜しみつつも， ウクライナ独立を歓迎する一見矛盾した態度は計 388 人（標本の $13.7 \%$ ） に観察される。 
表 3 主成分ベクトルとクラスターの解釈

\begin{tabular}{|c|c|c|c|c|c|c|c|}
\hline & \multicolumn{6}{|c|}{ 主成分分析 } \\
\hline & & 第 1 主成分 & 第 2 主成分 & 第 3 主成分 & 第 4 & 第 4 主成分 & 第 5 主成分 \\
\hline \multicolumn{2}{|r|}{ 命名： } & $\begin{array}{c}\text { アンチ } \\
\text { ウクライナ }\end{array}$ & $\begin{array}{l}\text { 独立ウクライナ } \\
\text { はロシアと兄弟 }\end{array}$ & $\begin{array}{l}\text { 国民史 } \\
\text { 象徵嫌 }\end{array}$ & & ソ連軍勝利 & $\begin{array}{c}\text { 独立万歳・ソ連 } \\
\text { ノタルジー }\end{array}$ \\
\hline \multicolumn{2}{|c|}{ RusChrist } & -0.03 & 0.20 & -0.41 & & 0.08 & -0.25 \\
\hline \multicolumn{2}{|c|}{ Khmelnytsky } & -0.04 & 0.28 & -0.58 & \multicolumn{2}{|c|}{0.29} & -0.27 \\
\hline \multicolumn{2}{|c|}{ Pereyaslav } & 0.44 & 0.75 & 0.08 & \multicolumn{2}{|c|}{-0.48} & 0.06 \\
\hline \multicolumn{2}{|r|}{ UPA } & -0.55 & -0.08 & -0.44 & \multicolumn{2}{|c|}{-0.66} & 0.20 \\
\hline \multicolumn{2}{|c|}{ WinNazis } & 0.03 & 0.16 & -0.29 & \multicolumn{2}{|c|}{0.32} & 0.01 \\
\hline \multicolumn{2}{|c|}{ USSREnd } & -0.60 & 0.34 & 0.44 & \multicolumn{2}{|c|}{0.01} & -0.57 \\
\hline \multicolumn{2}{|c|}{ Independence } & -0.38 & 0.41 & 0.11 & \multicolumn{2}{|c|}{0.37} & 0.71 \\
\hline \multicolumn{2}{|c|}{ 固有値平方根 } & 1.26 & 0.74 & 0.68 & \multicolumn{2}{|c|}{0.60} & 0.51 \\
\hline \multirow{2}{*}{\multicolumn{2}{|c|}{$\begin{array}{r}\text { 寄与率 } \\
\text { 累積寄与率 }\end{array}$}} & $43.7 \%$ & $15.0 \%$ & $12.8 \%$ & \multicolumn{2}{|c|}{$9.8 \%$} & $7.1 \%$ \\
\hline & & $43.7 \%$ & $58.7 \%$ & $71.6 \%$ & \multicolumn{2}{|c|}{$81.3 \%$} & $88.5 \%$ \\
\hline \multirow{6}{*}{ 主成分得点 } & 最大值 & 2.56 & 1.43 & 3.10 & \multicolumn{2}{|c|}{1.56} & 1.61 \\
\hline & 平均値 & 0.00 & 0.00 & 0.00 & \multicolumn{2}{|c|}{0.00} & 0.00 \\
\hline & 中間値 & -0.31 & -0.15 & -0.27 & \multicolumn{2}{|c|}{0.10} & -0.12 \\
\hline & 最小值 & -1.56 & -2.94 & -1.54 & & & -1.95 \\
\hline & & & & ラスター分惦 & & & \\
\hline & A & B & $\mathrm{C}$ & D & E & $\mathrm{F}$ & G \\
\hline 命名 & $\begin{array}{c}\text { ウク型 / } \\
\text { 反ロシア II }\end{array}$ & $\begin{array}{c}\text { ウク型/ } \\
\text { 対ロシア } \\
\text { 中立 }\end{array}$ & $\begin{array}{l}\text { ウク型/ } \\
\text { 親ロシア }\end{array}$ & $\begin{array}{l}\text { ウク型 / } \\
\text { 反ロシア I }\end{array}$ & $\begin{array}{c}\text { ウク型 / } \\
\text { 反民族主義 }\end{array}$ & $\begin{array}{l}\text { ソ連型／ } \\
\text { 反独立 }\end{array}$ & $\begin{array}{c}\text { ソ連型 / } \\
\text { ハイブリッ } \\
\text { ド }\end{array}$ \\
\hline RusChrist & 0.63 & 0.48 & 0.89 & 1.00 & 0.64 & 0.73 & 0.80 \\
\hline Khmelnytsky & 1.00 & -0.12 & 0.96 & 1.00 & 0.58 & 0.60 & 0.97 \\
\hline Pereyaslav & -1.00 & -0.15 & 0.71 & -1.00 & 0.00 & 0.44 & 0.49 \\
\hline UPA & 1.00 & 0.33 & 0.72 & 1.00 & -0.53 & -0.63 & -0.30 \\
\hline WinNazis & 0.36 & 0.24 & 0.83 & 1.00 & 0.98 & 0.98 & 0.98 \\
\hline USSREnd & 0.45 & 0.44 & 0.93 & 1.00 & 1.00 & -0.88 & -0.75 \\
\hline Independence & 1.00 & 0.47 & 0.98 & 1.00 & 1.00 & -0.51 & 1.00 \\
\hline & $\mathrm{n}=196$ & $\mathrm{n}=432$ & $\mathrm{n}=385$ & $\mathrm{n}=487$ & $\mathrm{n}=404$ & $\mathrm{n}=546$ & $\mathrm{n}=383$ \\
\hline & $6.9 \%$ & $15.2 \%$ & $13.6 \%$ & $17.2 \%$ & $14.3 \%$ & $19.3 \%$ & $13.5 \%$ \\
\hline
\end{tabular}

\section{(1) 世代}

第 1 主成分（アンチウクライナ）の世代間分布は図 1 のと抢りである。箱の真ん中付近の横 線が中央值, 箱上部の横線が第 3 四分位数, 箱下部の横線が第 1 四分位数, 箱の外の上下の短 い横線が最大值と最小值を表している。世代が上がるほど，わずかだが得点が増えているよう に見える。多重比較を行ったところ, 30 歳未満と 50 歳代・ 60 歳以上との間, 30 歳代と 60 歳 以上の間に平均值の有意な差が観察された。第 2 主成分（独立ウクライナとロシアは兄弟）は 世代間で統計的に有意な差異を示さなかった。

また，歴史観クラスターの世代間分布は図 2 のと抢り緩やかであるが，カイ 2 乗検定後の残 
差分析を行ったところ (表省略)，30 歳未満に「ソ連型／反独立」が有意に少ない。一方，60 歳以上には「ウク型／反民族主義」が少なく，「ソ連型／反独立」が多い。

Korostelina（2011）は，独立後のウクライナの歴史教育は国家アィデンティティの中心に被 害者意識を据え，ロシアを抑圧的，攻撃的な隣国として位置づけてきたと分析し，歴史教育に 対するそのようなアプローチはロシアとの関係を悪化させるだけでなく，国内の民族間の緊張 も高めるだろらと指摘している。しかし，第 2 主成分や「ウク型／反ロシア」のクラスターに 世代間の差は見られず，独立後の歴史教育の影響を直接受けるはずの若年層に反ロシア的な歴 史観が強まる兆候は表れていない。この結果は国家の歴史教育が個人の歴史観形成に与える影 響が限定的である可能性を示唆する。

\section{（2）居住地域}

第 1 主成分（アンチウクライナ）の地域間分布は図 3 のと抢りであり（点は四分位範囲の 1.5 倍の範囲を超える外れ值)，ほぼ全ての地域間に有意な差が観察された。ドンバスを筆頭に，

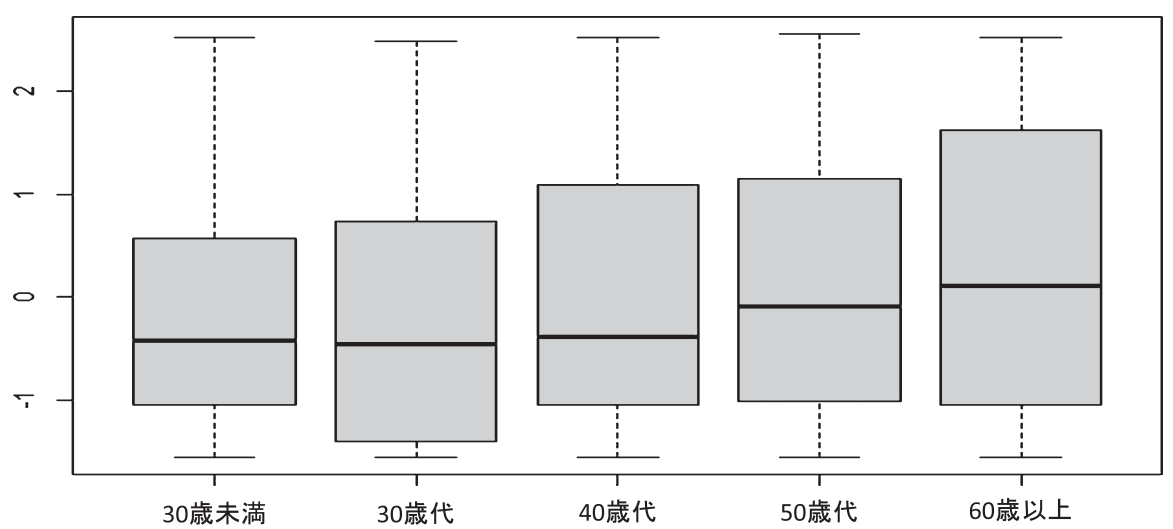

図 1 第 1 主成分（アンチウクライナ）の世代間分布

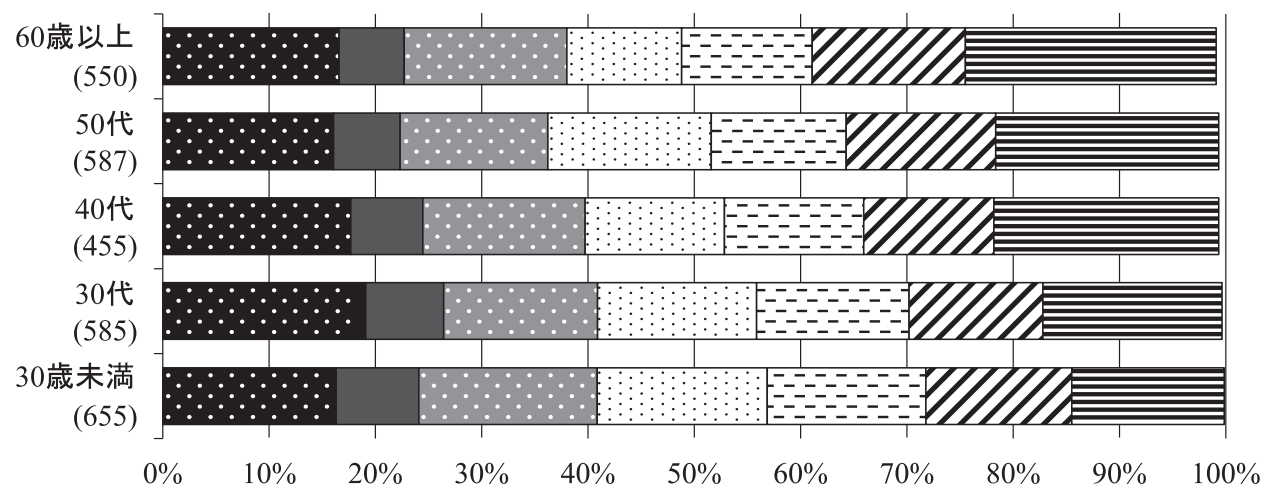

・ウク型/反ロシアI 曰ウク型/親ロシア 目ソ連型/反独立
ロウク型/反ロシアII 四ウク型/反民族主義
曰ウク型/対ロシア中立 ロソ連型/ハイブリッド

図 2 歴史観の世代間分布 
スロボダ，ドニエプル下流，黒海沿岸の順に高い。中央部のキエフ，左岸，右岸，ポジーリャ は注涪同水準であるが，西部の南西部（ハンガリー，ルーマニアとそれぞれ国境を接するザカ ルパッチャ，ブコヴィナを含を地域）はハリチナやヴォルィーニとは明らかに異なる傾向を示 している。

第 2 主成分（独立ウクライナとロシアは兄弟）の地域間分布（図 4）も，西部に括ける南西 部の突出する状況を示し, 同地域は八リチナやヴォルィーニとの差が有意である。また，東部 ではドニエプル下流がドンバス，スロボダと比べて有意に平均值が高い。南西部やドニエプル の「親ロシア」性は, 第 2 主成分が表現するようなウクライナ独立を前提とした穏健性に特徴 があるといえるかもしれない。

歴史観クラスターの地域間分布（図 5）は「歴史的地域」の領域内であっても居住者の歴史 認識が理想的均一性からは遠いことを示している。西部と中部（キエフ市含む）ではウクラィ ナ型の歴史観が優勢であるが，地域によって濃淡がある。反ロシアを伴らウクライナ型は八リ チナ及びヴォルイーニに多い。南西部にはハリチナのような反ロシアの影響はほとんど観察で きない。

東部に目を移せば，ドンバスはソ連型が圧倒的に優勢である。一方，スロボダ，ドニエプル

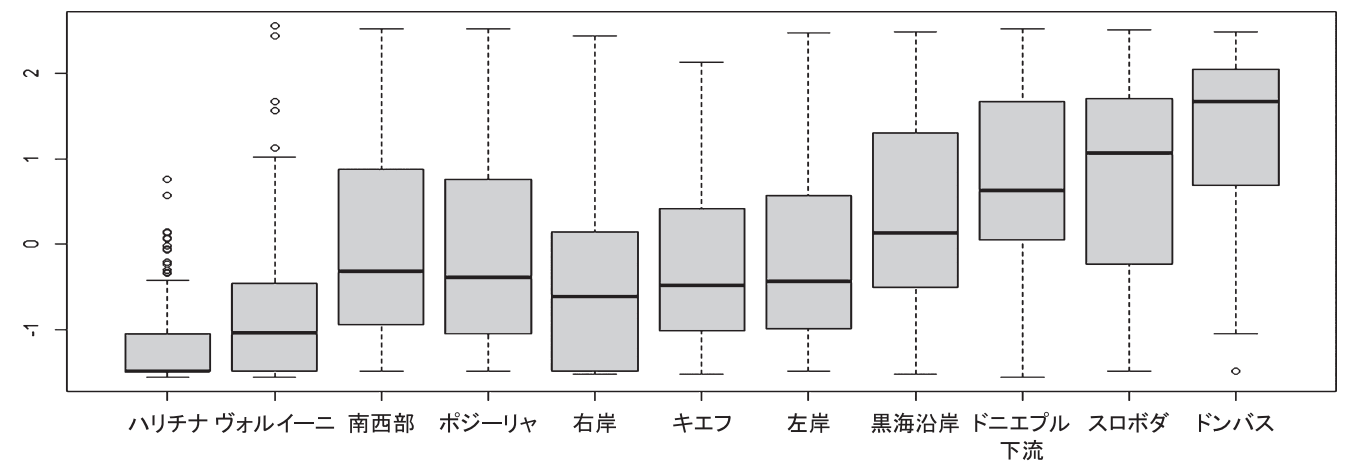

図 3 第 1 主成分（アンチウクライナ）の地域間分布

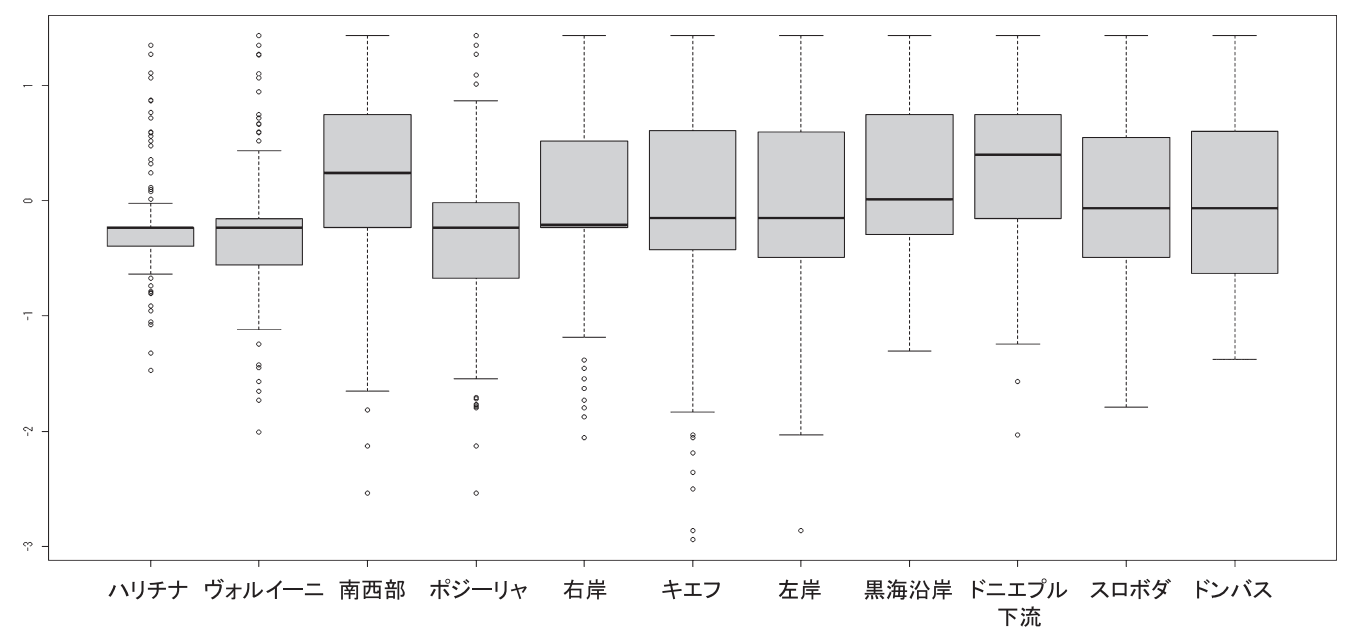

図 4 第 2 主成分（独立ウクライナとロシアは兄弟）の地域間分布 
下流，黒海沿岸ではウクライナ型とソ連型が拮抗するが，ドンバスに典型的な「ソ連型／反独 立」，八リチナに典型的な「ウク型／反ロシア」は支配的ではない。その代わりに「ソ連型／ ハイブリッド」や穏健なウクライナ型の歴史観が混在する。さまざまな形態の歴史観が重なり 合うこれらの不定形・不均質な地域は，東か西か，欧州かり連か，親ウクライナか親ロシアか を白黒つけようとする二項対立的な分析枠組みでは捉えきれるものではないだろら。

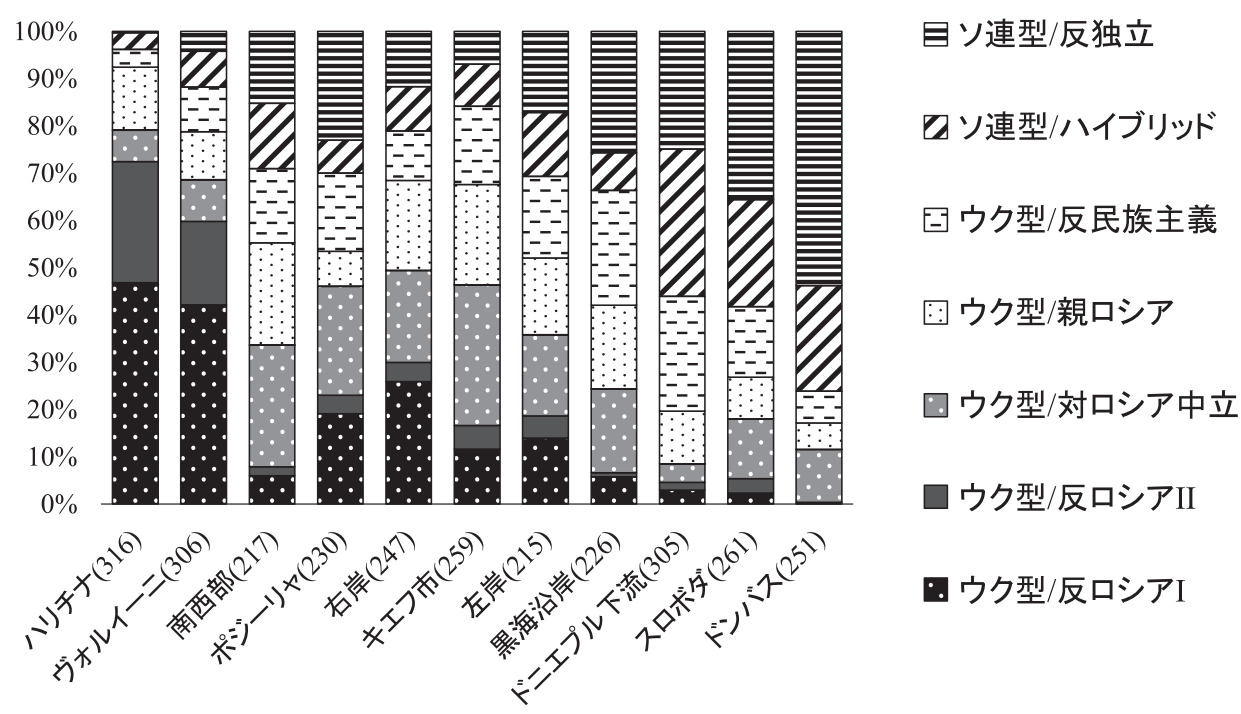

図 5 歴史観クラスターの地域間分布

\section{（3）民族属性・使用言語}

第 1 主成分（アンチウクライナ）の民族間分布（図 6）は直感のと括り，ロシア人はウクラ イナ人に比べ有意に高い值となって扣り，平均值の差も有意であった。一方，第 2 主成分（独 立ウクライナとロシアは兄弟）の民族間分布（図 7）は, ウクライナ人とロシア人の平均值に

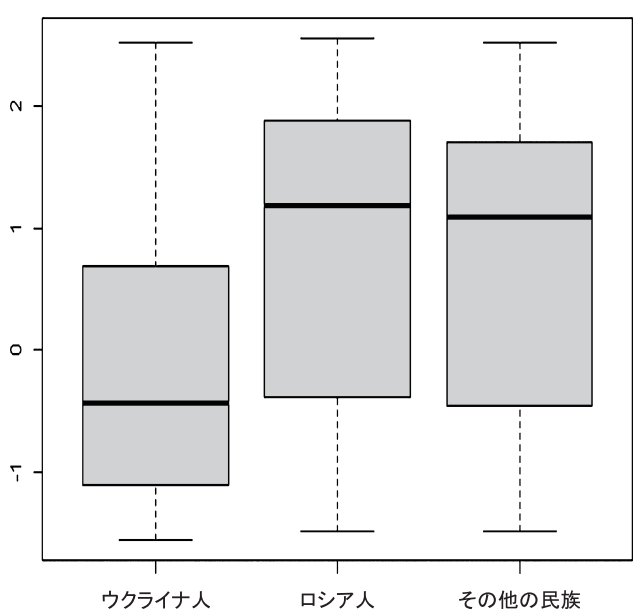

図 6 第 1 主成分（アンチウクライナ）の民 族間分布

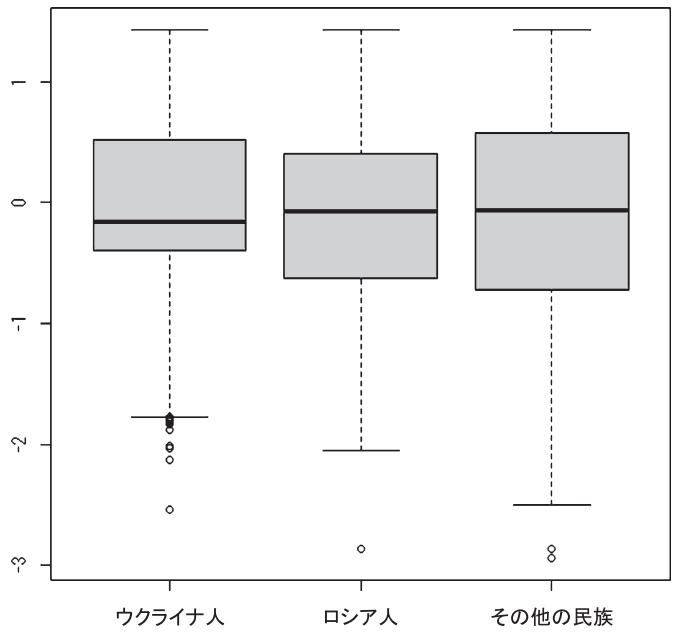

図 7 第 2 主成分（独立ウクライナはロシアと 兄弟）の民族間分布 


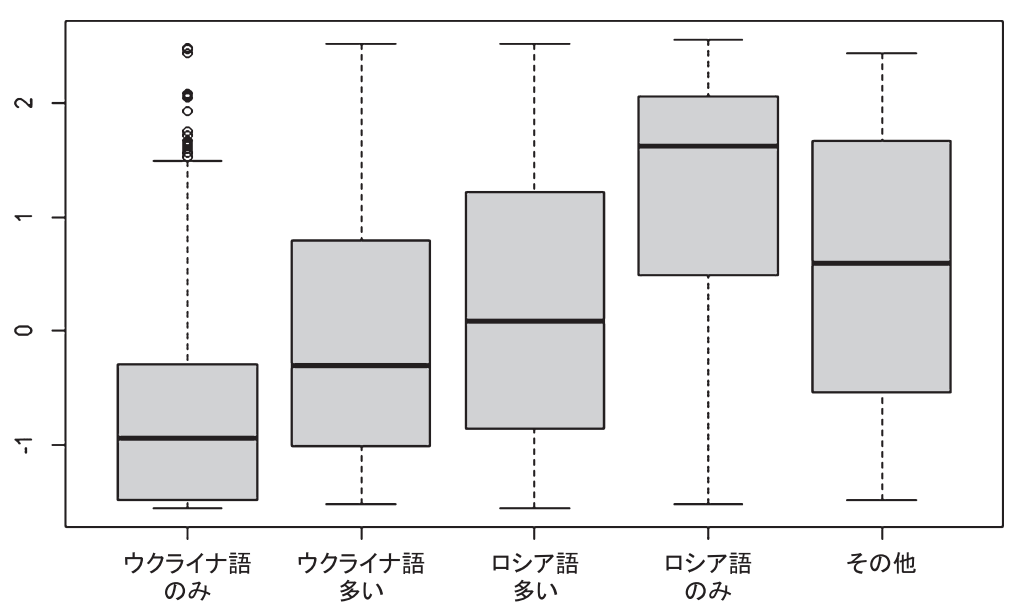

図 8 第 1 主成分（アンチウクライナ）の言語間分布

有意な差が確認されたものの, 図から第 1 四分位及び第 3 四分位ではウクライナ人がロシア人 よりも得点が高いことが分かる。

第 1 主成分の言語間分布（図 8）では，5群間すべてに有意な差が認められ，ロシア語の使 用頻度が高い汪ぞ得点が高くなる傾向が認められる。第 2 主成分の言語間分布（図省略）は一 部の群間に有意な差が認められるものの，第 1 主成分ほどに差が明瞭ではない。

\section{3 歴史観の効果}

調査対象者はユーロマイダンに対する態度（以下「マイダン態度」）を4つの選択肢（肯定的， 否定的，ぞちらともいえない，知らない）から回答している。本節ではこの回答を「肯定的> ぞちらともいえない>否定的」の順序变数として捉え順序ロジットによって推定する ${ }^{(7)}$ 。

\section{（1）推定の手順}

最初にウクライナの政治態度の計量分析において伝統的に重視されてきた民族，言語，地域 の 3 変数（e.g. Barrington \& Faranda 2009）を説明変数としてマイダン態度を順序ロジットで 回帰する（モデル 1)。先行研究に基づけば民族や言語を制御しても地域変数の偏回帰係数は 有意であるはずである。

次に，歴史観の第 $1 \sim 5$ 主成分（累積寄与率 88.5\%)，第 1 主成分のみ（寄与率 43.7\%）の 主成分得点を加えた（モデル 2 及び 3 )。地域変数の偏回帰係数の有意性がなくなれば，マイ ダン態度に対する地域変数の効果は, 歴史観によって媒介された可能性がある。

歴史観の効果の大きさを検証するにあたっては, 操作変数法によってマイダン態度と歴史観 の同時決定バイアスを取り除く必要がある。操作変数法の代表的手法として 2 段階最小二乗法 （2SLS）があるが，線形仮定に基づくため，順序ロジットにそのまま適用することはできない。 このため本稿では, マイダン態度を順序変数から連続変数に置き換え, 同じ外生变数で制御し

(7)「知らない」といら回答（若干数）は欠損值扱いとして分析から除外した。 
て最小二乗法（OLS）で回帰した結果が順序ロジットと大きく変わらないことを確認したらえ で（モデル 5 及び 6)，2SLSを準用した。

操作変数には, ソ連崩壊の前後で学校教育の内容が大きく転換したことに注目し, 1991 年 末のソ連崩壊時に初等教育（3 年生）を修了していたかどらか（2014 年末に 31 歳）を区切り として「非ソ連型」と「ソ連型」の 2 カテゴリからなる「教育」变数を回答者の調査時点の年 齢から合成した。さらに教育とマイダン態度に直接的関係がないといら仮定を確かめるため, 順序ロジット及び OLS で他の外生変数を制御したときに教育がマイダン態度とは相関しない ことを確認した（モデル 4 及び 7)。最後に教育を操作変数としてマイダン態度を 2SLS で回帰 した（モデル 8)。

\section{(2) 結果と解釈}

順序ロジットによる推定結果は表 4 のと抢りである。モデル 1 では，民族や言語で制御して も，ヴォルイーニを除く全ての地域が基準カテゴリのハリチナとの間で有意な差を示した。と くにドンバス，ドニエプル下流，スロボダ，ポジーリャがマイダンを強く否定する傾向にある。 ロシア語のみ話す者もウクライナ語のみに比べ否定的な傾向が有意に表れた。ロシア人は基準 カテゴリのウクライナ人との間に有意な差は観察できない ${ }^{(8)}$ 。

第 5 主成分まで歴史観変数を投入したモデル 2 では, 南西部, 右岸, キエフ市, 黒海沿岸, ドニエプル下流，スロボダ，ドンバスの地域カテゴリが統計的な有意性を失った。また，ヴォ ルイーニは偏回帰係数の正負が逆転した。一方，ポジーリャ及び左岸はハリチナとの有意な 差が残った。これらの地域にはマイダン態度を説明する歴史観以外の要因が存在する可能性が ある。

な怙，民族変数の「ロシア人」カテゴリが有意に正の值となったが，言語の各カテゴリの偏 回帰係数や有意性はほとんど变化していない。使用言語には歴史観から独立した安定した効果 があるともいえる。

\section{（3）頑健性の点検}

歴史観第 1 主成分得点を投入した場合の順序ロジットの推定結果を OLS の推定結果（表 5 のモデル 5 及び 6）と比較すると, 偏回帰係数の向きや有意性はほぼ同じであることが確認で きる。さらに, 操作変数の「教育」は順序ロジット及びOLS の双方でマイダン態度と相関し ないこと（表 4 モデル 4 及び表 5 モデル 7), 歴史観変数とは相関すること（表省略）を確認 した。これらの結果を踏ま兄，2SLSでマイダン態度に対する効果を推定した結果（表 5 モデ ル 8$)$, 歴史観第 1 主成分の効果は $5 \%$ の有意水準で否定された $(10 \%$ 水準では効果が確認さ れた)。

(8) 原調査の標本にロシア人が絶対多数を占めるクリミア自治共和国が含まれていないことに留意する必 要がある。一方, ウクライナに打ける民族変数の想定外の挙動については先行研究でも指摘がなされ ている。ルハンシクの地政学的アイデンティティを多項ロジスティック回帰で分析した Gentile (2015, 217）は，「自らをウクライナ人且つロシア人と見る者が参照グループのウクライナ人より西側に友好 的である」と報告する。また, ウクライナで仮想投票実験を行った Frye $(2014,16-17)$ も「自らの母語 をロシア語と申告した民族的ウクライナ人は, ロシア語を母語とする民族的ロシア人よりも，有意に 低いレベルで，ロシアとの経済関係の深化に反対した」と指摘する。 
表 4 順序ロジットによる推定結果

目的変数 : ユーロマイダンへの態度

\begin{tabular}{|c|c|c|c|c|c|c|c|c|}
\hline & \multicolumn{2}{|c|}{1 歴史観なし } & \multicolumn{2}{|c|}{$\begin{array}{c}2 \text { 歴史観主成分 } \\
\text { (累積 } 88.5 \% \text { ) }\end{array}$} & \multicolumn{2}{|c|}{$\begin{array}{c}3 \text { 歴史観主成分 } \\
\text { (累積 43.7\%) }\end{array}$} & 4 教育 & (IV) \\
\hline & B & S.E. & B & S.E. & B & S.E. & B & S.E. \\
\hline 歴史観 : 第 1 主成分 (アンチウクライナ) & & & $-1.391 * * *$ & 0.059 & $-1.282 * * *$ & 0.055 & & \\
\hline 第 2 主成分(独立・ロシア兄弟) & & & $0.160^{*}$ & 0.065 & & & & \\
\hline 第 3 主成分（国民史象徵嫌い） & & & $-0.600 * * *$ & 0.071 & & & & \\
\hline 第 4 主成分 (ソ連軍勝利) & & & 0.045 & 0.077 & & & & \\
\hline 第 5 主成分 (独立・ソ連ノスタル) & & & $0.658 * * *$ & 0.093 & & & & \\
\hline \multicolumn{9}{|l|}{ 民族属性：ウクライナ人（ref.） } \\
\hline ロシア人 & 0.102 & 0.145 & $0.623 * * *$ & 0.168 & $0.536^{* *}$ & 0.168 & 0.122 & 0.145 \\
\hline その他 & -0.550 & 0.287 & 0.222 & 0.325 & -0.079 & 0.325 & -0.530 & 0.289 \\
\hline \multicolumn{9}{|l|}{ 使用言語 : ウクライナ語のみ（ref.） } \\
\hline ウクライナ語多い & $-0.429 * *$ & 0.131 & $-0.592 * * *$ & 0.149 & $-0.384 * *$ & 0.149 & $-0.423 * *$ & 0.131 \\
\hline ロシア語多い & $-0.638 * * *$ & 0.141 & $-0.903 * * *$ & 0.161 & $-0.755^{* * *}$ & 0.161 & $-0.637 * * *$ & 0.141 \\
\hline ロシア語のみ & $-1.606 * * *$ & 0.181 & $-1.276 * * *$ & 0.205 & $-1.257 * * *$ & 0.205 & $-1.610^{* * *}$ & 0.181 \\
\hline その他 & -0.119 & 0.558 & -0.391 & 0.660 & -0.029 & 0.660 & -0.122 & 0.559 \\
\hline \multicolumn{9}{|l|}{ 居住地域：ハリチナ（ref.） } \\
\hline ヴォルイーニ & -0.038 & 0.356 & $0.881 *$ & 0.377 & $0.789^{*}$ & 0.377 & -0.042 & 0.356 \\
\hline 南西部 & $-1.910 * * *$ & 0.300 & 0.035 & 0.324 & -0.315 & 0.324 & $-1.912^{* * *}$ & 0.300 \\
\hline ポジーリャ & $-2.610^{* * *}$ & 0.296 & $-0.973 * *$ & 0.318 & $-1.398 * * *$ & 0.318 & $-2.616^{* * *}$ & 0.296 \\
\hline 右岸 & $-1.439 * * *$ & 0.308 & -0.052 & 0.329 & -0.386 & 0.329 & $-1.450 * * *$ & 0.308 \\
\hline キエフ市 & $-2.055 * * *$ & 0.300 & -0.496 & 0.317 & $-1.032 * *$ & 0.317 & $-2.076 * * *$ & 0.301 \\
\hline 左岸 & $-2.473^{* * *}$ & 0.300 & $-0.865^{* *}$ & 0.322 & $-1.168 * * *$ & 0.322 & $-2.485^{* * *}$ & 0.300 \\
\hline 黒海沿岸 & $-2.479 * * *$ & 0.309 & -0.291 & 0.336 & $-0.799 *$ & 0.336 & $-2.484 * * *$ & 0.309 \\
\hline ドニエプル下流 & $-2.642 * * *$ & 0.298 & -0.230 & 0.325 & -0.461 & 0.325 & $-2.654 * * *$ & 0.298 \\
\hline スロボダ & $-2.541 * * *$ & 0.309 & -0.172 & 0.337 & -0.492 & 0.337 & $-2.549 * * *$ & 0.309 \\
\hline ドンバス & $-2.982 * * *$ & 0.316 & -0.263 & 0.349 & -0.516 & 0.349 & $-2.987 * * *$ & 0.316 \\
\hline \multicolumn{9}{|l|}{ 教育 : 非ソ連型（ref.) } \\
\hline ソ連型 & & & & & & & -0.176 & 0.098 \\
\hline 閾值 : 否定的|どちらともいえない & -3.395 & 0.259 & -1.989 & 0.272 & -2.149 & 0.269 & -3.530 & 0.270 \\
\hline どちらともいえない|肯定的 & -2.960 & 0.257 & -1.357 & 0.271 & -1.557 & 0.268 & -3.095 & 0.268 \\
\hline $\mathrm{AIC}$ & \multicolumn{2}{|c|}{$4,096.65$} & \multicolumn{2}{|c|}{$3,217.49$} & \multicolumn{2}{|c|}{$3,352.08$} & \multicolumn{2}{|c|}{$4,095.09$} \\
\hline $\mathrm{BIC}$ & \multicolumn{2}{|c|}{$4,203.53$} & \multicolumn{2}{|c|}{$3,354.05$} & \multicolumn{2}{|c|}{$3,464.90$} & \multicolumn{2}{|c|}{$4,207.89$} \\
\hline 対数尤度 & \multicolumn{2}{|c|}{$-2,030.33$} & \multicolumn{2}{|c|}{$-1,585.75$} & \multicolumn{2}{|c|}{$-1,657.04$} & \multicolumn{2}{|c|}{$-2,028.54$} \\
\hline 逸脱度 & \multicolumn{2}{|c|}{$4,060.65$} & \multicolumn{2}{|c|}{$3,171.49$} & \multicolumn{2}{|c|}{$3,314.08$} & \multicolumn{2}{|c|}{$4,057.09$} \\
\hline 観测数 & \multicolumn{2}{|c|}{2800} & \multicolumn{2}{|c|}{2800} & 2800 & & 2799 & \\
\hline
\end{tabular}

$* * * \mathrm{p}<0.001, * * \mathrm{p}<0.01, * \mathrm{p}<0.05$

\section{おわりに}

「地域」はユーロマイダン以後のウクライナを手っ取り早く理解するキーワードのひとつだ が，居住地は介入によって動かすことができない変数である。地域変数を強調することは国民 統合へ向けた建設的な議論よりも屯しろ, ウクライナの分裂を不可避と見るロシア的「地政学」 の正当化や従来の地域間ステレオタイプの強化に寄与するだけのように思われる。本論で見た と沶り, 歴史観変数の投入によって東部の主要な地域の地域変数の効果が有意でなくなったこ とは, 歴史観が地域変数とマイダン態度をつなぐ有力な媒介変数である可能性を示唆している。 
表 5 OLS 及び 2SLS による推定結果

目的変数：ユーロマイダンへの態度（肯定的：1, ぞちらともいえない：0, 否定的：-1）

\begin{tabular}{|c|c|c|c|c|c|}
\hline & & $\begin{array}{c}5 \text { 歴史観 } \\
\text { なし }\end{array}$ & $6 \begin{array}{c}\text { 歴史観 } \\
\text { 主成分 }\end{array}$ & 7 教育 (IV) & $8 \quad 2$ SLS \\
\hline 定数項 : & & $0.918^{* * *}$ & $0.393 * * *$ & $0.959 * * *$ & $0.491 *$ \\
\hline 歴史観： & 第 1 主成分（アンチウクライナ） & & $-0.421^{* * *}$ & & $-0.342+$ \\
\hline \multirow[t]{3}{*}{ 民族属性： } & ウクライナ人 (ref.) & & & & \\
\hline & ロシア人 & 0.030 & $0.141^{* *}$ & 0.037 & $0.120+$ \\
\hline & その他 & $-0.248^{*}$ & -0.026 & $-0.245^{*}$ & -0.069 \\
\hline \multirow[t]{5}{*}{ 使用言語： } & ウクライナ語のみ（ref.） & & & & \\
\hline & ウクライナ語多い & $-0.159 * * *$ & $-0.107 * *$ & $-0.157 * * *$ & $-0.117 * *$ \\
\hline & ロシア語多い & $-0.263 * * *$ & $-0.232 * * *$ & $-0.262 * * *$ & $-0.238 * * *$ \\
\hline & ロシア語のみ & $-0.706 * * *$ & $-0.419 * * *$ & $-0.706^{* * *}$ & $-0.473 * * *$ \\
\hline & その他 & -0.064 & -0.035 & -0.061 & -0.039 \\
\hline \multirow[t]{11}{*}{ 居住地域 : } & ハリチナ（ref.） & & & & \\
\hline & ヴォルイーニ & 0.036 & $0.177^{* *}$ & 0.035 & $0.151+$ \\
\hline & 南西部 & $-0.333 * * *$ & $0.142 *$ & $-0.334 * * *$ & 0.053 \\
\hline & ポジーリャ & $-0.676^{* * *}$ & $-0.225 * * *$ & $-0.677 * * *$ & -0.310 \\
\hline & 右岸 & $-0.195^{* *}$ & 0.083 & $-0.198 * *$ & 0.031 \\
\hline & キエフ市 & $-0.411 * * *$ & -0.105 & $-0.417 * * *$ & -0.163 \\
\hline & 左岸 & $-0.619^{* * *}$ & $-0.177^{* *}$ & $-0.623^{* * *}$ & -0.260 \\
\hline & 黒海沿岸 & $-0.624 * * *$ & -0.046 & $-0.624 * * *$ & -0.154 \\
\hline & ドニエプル下流 & $-0.699 * * *$ & 0.045 & $-0.702 * * *$ & -0.095 \\
\hline & スロボダ & $-0.646^{* * *}$ & 0.064 & $-0.647 * * *$ & -0.069 \\
\hline & ドンバス & $-0.896 * * *$ & -0.032 & $-0.897 * * *$ & -0.194 \\
\hline \multicolumn{6}{|c|}{ 教育：非ソ連型（ref.) } \\
\hline & ソ連型 & & & -0.055 & \\
\hline 調整済及 $\mathrm{R}^{2}$ & & 0.256 & 0.455 & - & - \\
\hline
\end{tabular}

*** $\mathrm{p}<0.001, * * \mathrm{p}<0.01, * \mathrm{p}<0.05$, (以下はモデル 8 のみ） $+\mathrm{p}<0.1$

一方で，分析を通じて以下のような課題が新たに浮かび上がった。

(1)ポジーリャ及び左岸のように歴史観主成分を投入しても, 地域変数の効果が有意な地域があ る。本分析は, 地域によらず歴史観の効果は全国一様と仮定したが, 分析の結果は地域によっ て歴史観主成分の効果が異なる可能性も示唆している。歴史観の主効果だけでなく, 歴史観 と地域の交互作用効果の検証が求められる。

(2)歴史観がユーロマイダンへの態度に与えた因果的効果は本稿の枠内では統計的に立証されて いない。クロスセクションデータの限界はあるものの, より適切な操作変数を見つけるなど, 同時決定バイアスに対処して真の効果に迫ることが望まれる。

(3)本分析では, 筆者の力量不足で原調査の歴史観に関連する全ての情報を余すことなく活用で きたとは言い難い。今回活用できなかった情報（例えば, リストワイズ削除した「知らない」 という回答）を含め, 異なるデータや手法によって歴史観を合成した場合にどのような結果 となるか碩健性をさらに検証してみることが必要である。

なお，本研究の過程で興味深い現象が観察された。Sereda（2007）は，2004 年のドネック 
での歴史認識調査（n=316）に扔いて，最も肯定的な歴史的出来事として「ウクライナ独立」 を挙げた者が相対多数であったこと（n=122，27.7\%)，それと同時に最も否定的な歴史的出 来事として「ソ連崩壊とウクライナ独立」と回答した者が相対多数であったこと（n=83, 20.3\%）を指摘し，「ドネック人の歴史アイデンティティに拈ける内部矛盾」と呼んだ。この 結果からはドネックで独立支持派とソ連支持派が拮抗していると理解寸ることもできるが，本 稿のハイブリッド型の歴史観に見られたように，実はそのような矛盾した歷史認識は集計デー タだけでなく個票データ，すなわち多くの個人の中でも起こっている。個人の歴史観は歴史年 表のように整合のとれたものではない(9)。

歴史の「断続性」や「欠如」さえも容認しつつ, トランスナショナルな視点から線形的で均 質性の高いウクライナの国民史を見直そうとする動き（Kasianov \& Ther 2009）や，NGO が主 導する地域間対話の試み（ICPS 2015）も始まっている。ポスト・マイダンの国民統合の成否は, 新生ウクライナが従来の国民国家の価值尺度では測れない多様な歴史観をどこまで内在化でき るかにかかっているといっても過言ではないだろう。

\section{参 考 文 献}

Barrington, L.W. (2002), "Examining rival theories of demographic influences on political support: The power of regional, ethnic, and linguistic divisions in Ukraine", European Journal of Political Research, 41, 4.

Barrington, L.W. \& Herron, E.S. (2004), "One Ukraine or many? Regionalism in Ukraine and its political consequences", Nationalities Papers, 32,1 .

Barrington, L.W. \& Faranda, R. (2009), "Reexamining region, ethnicity, and language in Ukraine", Post-Soviet Affairs, 25, 3 .

Birch, S. (2000), "Interpreting the regional effect in Ukrainian politics", Europe-Asia Studies, 52, 6.

DIF (2015a), "Shcho ob'iednue ta roz'iednuie ukrajintsiv: opytuvannia hromads'koji dumky Ukraini", The Ilko Kucheriv Democratic Initiatives Foundation, available at: http://www.dif.org.ua/ua/polls/2015a/shoobednue-ta-rozednue-.htm, accessed 30 May 2016.

DIF (2015b), "Rezul'taty sotsiologicheskogo issledovaniiya, provedennogo v ramkakh proekta 'Initsiirovanie Natsional'nogo dialoga v Ukraine", The Ilko Kucheriv Democratic Initiatives Foundation, available at: http://ndialog.org.ua/uploads/files/rezultati $\% 20$ sociologichnogo $\% 20$ opituvannya $\% 20-\% 20$ regionalniy $\% 20$ rozriz/00_Survey_Ukraine_ru.pdf, accessed 30 May 2016.

Frye, T. (2014), "What Do Voters in Ukraine Want? A Survey Experiment on Candidate, Language, Ethnicity and Policy Orientation", available at: http://papers.ssrn.com/sol3/Papers.cfm?abstract_id=2477440, accessed 30 May 2016.

Gentile, M. (2015), "West oriented in the East-oriented Donbas: a political stratigraphy of geopolitical identity in Luhansk, Ukraine", Post-Soviet Affairs, 31, 3.

ICPS (2015), “Natsional'nyi dialoh v Ukrajini: yaki shansy na uspikh?”, International Centre for Policy Studies, 13 July, available at: http://icps.com.ua/natsionalnyy-dialoh-v-ukrayini-yaki-shansy-na-uspikh/, accessed 30 May 2016.

Kasianov, G. \& Ther, P. (eds.) (2009), A Laboratory of Transnational History: Ukraine and Recent Ukrainian Historiography, Budapest: Central European University Press.

Katchanovski, I. (2006), "Regional Political Divisions in Ukraine in 1991-2006”, Nationalities Papers, $34,5$.

(9) Nikolayenko（2008）は歴史観に対するコンテクスト効果の研究において「ロシアの青年層に見られる ソビエト・ノスタルジーと［現代ロシアの］国家的威信の両立」を指摘している。ロシアがソ連の法 的継承者であること，ソ連史学と現代ロシア史学の間の継続性からすれば， ロシアとソ連のアイデン ティティが合体したところで，個人の歷史認識に深刻な葛藤をもたらすようには見えない。一方，ソ 連史学から決別したウクライナの個人はこれとは対照的な状沉に置かれている。本稿で見たハイブ リッド型史観はり連の過去と独立後の現実的必要性を強制結婚させて出来上がった新型のナラティヴ なのか，それとも移行期特有の一時的現象なのか。これらを明らかにするためには継続的なモニタリ ングが必要となる。 
Korostelina, K. (2011), "Shaping unpredictable past: National identity and history education in Ukraine", National Identities, 13, 1 .

Nikolayenko, O. (2008), "Contextual effects on historical memory: Soviet nostalgia among post-Soviet adolescents", Communist and Post-Communist Studies, 41, 2.

O’Loughlin, J. (2001), “The regional factor in contemporary Ukrainian politics: scale, place, space, or bogus effect?", Post-Soviet Geography and Economics, 42, 1.

Osipian, A.L. \& Osipian, A.L. (2012), "Regional Diversity and Divided Memories in Ukraine: Contested Past as Electoral Resource, 2004-2010”, East European Politics \& Societies, 26, 3.

Panchenko, T.V. (2015), "Osoblyvyy status terytoriy yak faktor poperedzhennya ta vrehulyuvannya konfliktiv: mozhlyvosti vprovadzhennya dlya terytoriy Donbasu”, Visnyk Kharkivs'koho natsional'noho universytetu imeni V. N. Karazina. Seriya "Pytannya politolohiyi", 28.

Plokhy, S. (2001), "The Ghosts of Pereyaslav: Russo-Ukrainian Historical Debates in the Post-Soviet Era", Europe-Asia Studies, 53, 3.

Portnov, A. (2010), Uprazhneniia s istoriei po-ukrainski, Moscow: OHY.

Portnov, A. (2013), "Memory Wars in Post-Soviet Ukraine (1991-2010)", in Blacker, U., Etkind A. \& Fedor, J. (eds.) Memory and Theory in Eastern Europe. Palgrave Studies in Cultural and Intellectual History, Hounmills: Palgrave Macmillan.

Portnov, A. (2015), “The Heart of Ukraine'? Dnipropetrovsk and the Ukrainian Revolution”, in Wilson, A. (ed.) What does Ukraine think?, available at: http://www.ecfr.eu/page/-/WHAT_DOES_UKRAINE_THINK_ pdf.pdf, accessed 30 May 2016.

Putin, V. (2014a), "Address by President of the Russian Federation, Moscow, Kremlin", March 18, available at: http://eng.kremlin.ru/news/6889, accessed 30 May 2016.

Putin, V. (2014b), "Press-Conference", March 4, available at: http://eng.kremlin.ru/news/6763, accessed 30 May 2016.

Riabchuk, M. (2015), “'Two Ukraines’ Reconsidered: The End of Ukrainian Ambivalence?”, Studies in Ethnicity and Nationalism, 15,1 .

Sereda, V. (2007), "Regional Historical Identities and Memory", in Hrytsak, Y., Portnov, A. \& Susak, V. (eds.) L'viv-Donets'k: sotsial'ni identychnosti v suchasnii Ukraini. Ukraina Moderna, available at: http://www. timeandspace.lviv.ua/files/session/Sereda_185.doc, accessed 30 May 2016.

Zaharchenko, T. (2013), "Polyphonic Dichotomies: Memory and Identity in Today's Ukraine”, Demokratizatsiya, $21,2$.

Zhurzhenko, T. (2015), "Ukraine's Eastern Borderlands: The end of ambiguity”, in Wilson, A. (ed.) What does Ukraine think?, available at: http://www.ecfr.eu/page/-/WHAT_DOES_UKRAINE_THINK_pdf.pdf, accessed 30 May 2016.

（付記）本論はロシア・東欧学会 JSSEES 2016 年合同研究大会自由論題分科会における報告を もとにしている。同分科会座長の岩㟝一郎教授, 討論者の松里公孝教授, 査読者の諸 氏から頂いた建設的な助言にお礼申し上げます。

（本論文は，複数のレフェリーによる審査を経て編集委員会が採択した。） 